\title{
ANALISA PROMOSI PENJUALAN DAN PERIKLANAN TERHADAP HASIL PENJUALAN AIR MINERAL
}

\author{
Oleh: \\ Sumarsid ${ }^{1}$ \\ Atik Budi Paryanti ${ }^{2}$ \\ ${ }^{1}$ Program Studi Ilmu Manajemen \\ Sekolah Tinggi Ilmu Ekonomi Labora \\ ${ }^{2}$ Program Studi Sistem Informasi \\ Sekolah Tinggi Ilmu Komputer Cipta Karya Informatika \\ Email: \\ sumarsiddpk05@gmail.com ${ }^{1)}$,atikbudiparyanti@gmail.com ${ }^{2)}$
}

\begin{abstract}
PT. Tirta Investama (Danone Group) is a company manufacturer of mineral water with the AQUA brand. Because of the many companies that produce similar products i.e. mineral water then the competition happens to be very tight. To be able to compete in the market of mineral water PT. Tirta Investama did a promotional strategy including sales promotions and advertising for all products of mineral water AQUA. Based on the results of the analysis of the multiple correlation coefficient obtained correlation coefficient value of $\mathrm{X}_{1}$ cost of sales promotions and $\mathrm{X}_{2}$ the cost of advertising is 0.976 . Thus the cost of sales promotions and advertising fees have a very strong relationship and positive results against sales of mineral water AQUA packaging 600 milliliters PT. Tirta Investama.

Based on the results of the analysis of multiple linear regression can be known that any increase in the cost of sales promotions per USD 1,-, it will result in an increment amounting to Rp 0,952 sales results. Whereas an increase in the cost of advertising per Rp 1-then increment will result in proceeds of $\$ 1,279$,-thus it can be concluded that if companies do plan to add to the cost of advertising or promotional then the sales volume will increase.

Based on the results of the analysis of the determining coefficient (KP) obtained registration $=0.952$ or $95.2 \%$. milliliter on means a percentage of the sales

promotion costs and influence the cost of advertising against product sales results AQUA mineral water packaging 600 milliliteron PT. Tirta Investama amounted to $95.2 \%$ is affected by other factors that are not the meticulous writer.

Calculation based on hypothesis test with t-test shows that the variable cost of sales promotions, as well as variable costs partially influential advertising significantly to sales results. And based on the hypothesis test with test $\mathrm{F}$ it can be concluded that the cost of sales promotions and advertising costs simultaneously
\end{abstract}


affect significantly to sales of mineral water AQUA packaging 600 milliliters on PT. Tirta Investama.

Key Words: advertising, sales promotion, sales results

\section{A. PENDAHULUAN}

Bauran promosi sebagai salahsatucara perusahaan untuk menyampaikan pesan produk yang ditawarkan kepada komsumen, memegang peranan yang penting dalam mendukungmemperoleh tujuan program dari suatu pemasaran yang dilakukan oleh perusahaan, misalnya periklanan merupakan salahsatucara produsen memperkenalkan produk yang tujuannya antara lain untuk mengetahui produk yang baru, membujuk, membuat kesan dan memberi informasi, dengan periklanan yang baik maka akan tercapai suatu hasil yang diharapkan dan dapat mempengaruhifluktuasi volume penjualan.Dalam perekonomian modern periklanan juga makin lama semakin mendapatkan tempat yang tidak terpisahkan dengan masyarakat. Karenanya periklanan mempunyai peranan yang cukup besar bagi kegiatan penjualan.

PT. Tirta Investama (Danone Group) adalah perusahaan penghasil produkmakanan dan minumann dan salah satu produknya adalah air mineral dengan merk AQUA.AQUAmerupakan produk air mineral yang sangat terkenaldi Indonesia dan menjadi pelopor perkembangan industri air mineral yang ada di Indonesia.

Karena perkembangan dan banyaknya perusahaan yang menghasilkan produk sejenis yaitu air mineral maka persaingan yang terjadi menjadi sangat ketat.Untuk bisa berkompetisi di pasar air kemasan mineral PT. Tirta Investama melakukan strategi promosi diantaranya melalui promosi penjualan dan periklanan bagi seluruh produk air mineral AQUAsebagai penunjang keberhasilan dalam memperoleh kepercayaan yang berkesinambungan dari seluruh konsumen di Indonesia. Disinilah peran promosi penjualan dan periklanan akan sangat mempengaruhi terhadap hasil penjualannya.

\section{B. KAJIAN PUSTAKA}

\section{Manajemen Pemasaran}

Pemasaran bukan hanya berarti penjualan atau periklanan saja, tetapi pemasaran terdiri dari serangkaian konsep untuk memilih pasar sasaran, mengevaluasi keinginan dan kebutuhan konsumen, menentukan serta mengembangkan barang atau jasa dari pemuas keinginan, memberikan manfaat kepada konsumen yang akhirnya akan mendatangkan laba bagi perusahaan. Sehingga pemasaran lebih berkaitan dengan pelanggan dibandingkan fungsi bisnis lainnya.Memahami, membuat, mengkomunikasikan, dan memberi nilai serta kepuasan pelanggan adalah inti pemikiran dan aplikasi pemasaran modern.

Pemasaran dapat pula diartikan sebagai proses pemberian kepuasan kepada konsumen untuk mendapatkan laba. Dua sasaran pemasaran yang utama adalah 
menarik konsumen baru dengan menjanjikan nilai yang unggul dan mempertahankan konsumen saat ini dengan memberikan kepuasan.

Berikut ini akan penulis uraikan bebepara pengertian manajemen pemasaran dari para ahli pemasaran diantaranya yaitu:Pengertian tentang pemasaran menurut (Kotler, 2006, p. 8), "Suatu proses sosial dan merupakan manajerial dari individu dan kelompok dalam memperoleh kebutuhan dan keinginan mereka dengan membuat, menawarkan dan bertukar sesuatu yang bermanfaat satu sama lain".

Manajemen pemasaran menurut(Alma, 2011, p. 130)adalah: "Kegiatan menganalisa, mengimplementasikan dan mengawasi segala kegiatan (program) guna memperoleh tingkat pertukaran yang menguntungkan dengan target pasar dalam rangka mencapai tujuan organisasi."

Sedangkan pengertian tentang konsep pemasaran menurut (Dharmmesta, 2006, p. 10)sebagai berikut: "Konsep pemasaran adalah sebuah falsafah bisnis yang merupakan bahwa pemuasan kebutuhan konsumen merupakan syarat ekonomi dan sosial bagi kelangsungan hidup perusahaan."

Dari definisi yang telah diuraikan di atas dapat diambil kesimpulan bahwa dasar dari pemasaran adalah pemenuhan kebutuhan dan keinginan perorang serta kelompok, yang bertujuan untuk memahami dan mengetahui kebutuhan dan harapan konsumen secara lebih baik, sehingga produk yang ditawarkan dapat memuaskan kebutuhan dan harapan tersebut. Pada intinya pemasaran merupakan suatu cara yang dilakukan oleh manusia dalam rangka memenuhi apa yang dibutuhkan dan diinginkannya melalui suatu cara yang disebut pertukaran.

\section{Strategi Bauran Pemasaran}

Setelah mendesain pasar sasaran dan strategi pemasaran untuk bersaing secara keseluruhan yang telah ditentukan melalui riset pemasaran, langkah selanjutnya adalah bagaimana caranya perusahaan agar dapat mengakibatkan konsumennya adalah hal yang membutuhkan perencanaan dan pengawasan yang sangat baik serta perlu dilakukan tindakan-tindakan nyata dan terprogram.

Untuk keperluan tersebut perusahaan bisa melakukan perbuatan yang berkaitan dengan produk, harga, promosi dan distribusi.Perpadauan keempat hal itu merupakan senjata bagi perusahaan dalam memasarkan produknya atau melayani konsumennya. Senjata tersebut adalah "Bauran Pemasaran" atau biasa disebut "Marketing Mix."

Pengertian bauran pemasaran menurut(Kotler \& Amstrong, 2012, p. 101)menyatakan bahwa marketing mix merupakan seperangkat alat pemasaran yang digunakan perusahaan untuk terus menerus mencapai tujuan pemasarannya di pasar sasaran”.Pengertian marketing mix menurut(Alma, 2011, p. 130)adalah sebagai berikut: "Marketing mix merupakan strategi mencampur kegiatankegiatan marketing, agar dicari kombinasi maksimal sehingga mendatangkan hasil yang memuaskan."Menurut(Kotler \& Amstrong, 2012, p. 181)bauran pemasaran dapat diklasifkasikan mejadi 4P.Adapun keempat variabel tersebut dijelaskan secara singkat sebagai berikut:

a. Produk/product

Produk adalah sekumpulan manfaatharapan yang kompleks. Nilai sebuah produk ditetapkan oleh pembeli berdasarkan manfaat yang akan mereka 
terima. Mengelola unsur produk termasuk perencanaan pengembangan produk.

b. Harga/price

Sejumlah manfaat yang ditukarkan konsumen dengan manfaat lain dari memiliki atau menggunakan barang atau jasa yang nilainya ditetapkan oleh pembeli dan penjual melalui proses tawar menawar, atau ditetapkan oleh penjual untuk satu harga yang sama terhadap semua pembeli.

c. Tempat/place

Tempat diartikan sebagai saluran distribusi yang capaiannya untuk mencapai sasaran konsumen.Sistem distribusi ini mencakup lokasi, transportasi, pergudangan, dan sebagainya.

d. Promosi/promotion

Merupakan kegiatan yang dilakukan oleh perusahaan untuk mengkomunikasikan manfaat dari produknya dan untuk meyakinkan konsumen sasaran agar membeli produk tersebut. Salah satunya dengan service dimana service adalah Pelayanan terhadap konsumen menjadi sangatlah penting, Kemajuan perusahaan juga ditentukan dari variabel ini, apakah para pemakai tersebut tertarik dan merasa sesuai harapan dengan service yang dimiliki oleh perusahaan, sehingga memungkinkan para pengguna untuk memindahkan perhatian ke pesaing-pesaing bisnis yang lain. Oleh karena itu diperlukan beberapa hal yang dinilai penting dalam mempertahankan konsumen yang dimiliki perusahaan.Sistem harus bisa memperoleh informasi yang harapankan oleh pengguna dengan tepat; b) Hasil yang didapatkan dari sebuah sistem harus konsisten; c) Informasi yang diperoleh harus dapat diandalkan sehingga konsumen dapat percayaatas informasi yang didapatkan oleh pengguna; d) Sistem yang diaplikasikan atau digunakan harus mudah dipelajari, dimengerti dan mudah untuk dimanfaatkan oleh pengguna, sehingga pengguna akan merasa nyaman dalam menggunakan sistem informasi tersebut; e) Sistem harus bersifat fleksibel dan kompatibel.

Kelima variabel yang terdapat dalam kombinasi tersebut saling memiliki hubungan. Lagi pula kita mengksji konsep sistem sebagai keputusan yang masingmasing elemen di dalamnya saling mempengaruhi juga, setiap variabel yang ada mempunyai banyak sekali sub variabel. Kombinasi dari variabel bauran pemasaran yang digunakan oleh setiap perusahaan akan memiliki perbedaan tergantung dari strategi pemasaran yang dijalankannya. Selain itu variabel marketing mix atau bauran pemasaran yang digunakan harus disesuaikan dengan situasi dan kondisi yang telah ada, sehingga target penjualan dapat dicapai, ini berarti produk yang ditawarkan harus sesuai dengan kebutuhan serta keinginan konsumen, harus menjadikan produk yang dapat diperoleh dan tersedia bagi konsumen sasarannya dan dipromosikan melalui alat promosi yang tepat.

\section{Promosi}


Promosi berasal dari kata promote dalam bahasa Inggris yang diartikan sebagai mengembangkan atau meningkatkan. Promosi merupakan salah satu komponen dari bauran pemasaran (marketing mix) yang juga sangat penting dilakukan oleh perusahaan dalam memasarkan produknya yang pada akhirnya menjadi faktor penentu keberhasilan suatu program pemasaran

Untuk memberikan gambaran lebih jelas mengenai promosidibawah ini penulis mengemukakan pendapat dari beberapa ahlidiantaranya :

Menurut(Kotler \& Keller, 2007, p. 266) promosi adalah unsur utama dalam kampanye pemasaran sebagai kumpulan alat intensif yang sebagian besar berjangka pendek, yang dirancang untuk merangsang pembelian produk atau jasa tertentu dengan lebih cepat dan lebih besar kepada konsumen.

Menurut (Alma, 2011, p. 179) pengertian promosi adalah: "Promosi itu adalah sejenis komunikasi yang memberikan penjelasan yang meyakinkan calon konsumen tentang barang dan jasa. Tujuan promosi ialah memperoleh perhatian, mendidik, mengingatkan, dan meyakinkan calon konsumen."

Berdasarkan pengertian di atas dapat disimpulkan bahwa promosi adalah kegiatan perusahaan untuk melakukan komunikasi yang memberi penjelasan yang dapat meyakinkan dan merangsang pembelian produk dan jasa oleh target pasar.

Sedangkan pengertian bauran promosi atau promotional mix adalah kombinasi strategi yang paling baru dari variabel-variabel periklanan, personal selling dan alat-alat promosi lain yang kesemuanya direncanakan untuk mencapai tujuan perusahaan.

Definisi bauran promosi yang dikemukakan oleh (Kotler \& Amstrong, 2012, p. 432) sebagai berikut; "Promotion Mix adalah total sebuah perusahaan terdiri dari ramuan khusus pemasangan iklan, penjualan personal, promosi penjualan, hubungan masyarakat, dan alat-alat pemasaran langsung yang digunakan oleh perusahaan untuk mencapai tujuan-tujuan pemasangan iklan dan pemasaran".

Menurut (Kotler \& Amstrong, 2012, p. 432), bauran promosi terdiri atas 5 (lima) alat-alat promosi, yaitu:

a. Advertising (periklanan),

Yaitu semua bentuk presentasi dan promosi nonpersonal yang dibayar oleh sponsor untuk mempresentasikan ide, barang atau jasa. Periklanan dianggap sebagai manajemen citra yang bertujuan menciptakan dan memelihara cipta dan makna dalam benak konsumen. Bentuk promosi yang digunakan mencakup broadcast, print, internet, outdoor, dan bentuk lainnya.

b. Sales promotion (promosi penjualan),

Yaitu insentif-insentif jangka pendek untuk mendorong pembelian atau penjualan suatu produk atau jasa. Bentuk promosi yang digunakan mencakup discounts, coupons, displays, demonstrations, contests, sweepstakes, dan events.

c. Personal selling (penjualan perseorangan),

Yaitu presentasi personal oleh tenaga penjualan dengan tujuan menghasilkan penjualan dan membangun hubungan dengan konsumen. Bentuk promosi yang digunakan mencakup presentations, trade shows, dan incentive programs. 
d. Public relations (hubungan masyarakat),

Yaitu membangun hubungan yang baik dengan berbagai publik perusahaan supaya memperoleh publisitas yang menguntungkan, membangun citra perusahaan yang bagus, dan menangani atau meluruskan rumor, cerita, serta event yang tidak menguntungkan. Bentuk promosi yang digunakan mencakup press releases, sponsorships, special events, dan web pages.

e. Direct marketing (penjualan langsung)

Yaitu hubungan langsung dengan sasaran konsumen dengan tujuan untuk memperoleh tanggapan segera dan membina hubungan yang abadi dengan konsumen.Bentuk promosi yang digunakan mencakup catalogs, telephone marketing, kiosks, internet, mobile marketing, dan lainnya.

\section{Penjualan}

Penjualan adalah salah satu hal yang penting bagi perusahaan, penting di sini karena proses di mana produk yang telah diproduksi akan mengalami pertukaran dengan konsumen. Untuk memasarkan produknya perusahaan harus membuat sistim penjualan yang baik sesuai dengan perubahan pasar dan perilaku pelanggan, dengan demikian dapat terjalin hubungan yang baik dan menciptakan kepuasaan untuk keduanya.

Pengertian penjualan yang disampaikan oleh(Dharmmesta, 2006, p. 403): "Penjualan adalah interaksi antara individu saling bertemu muka yang ditujukan untuk menciptakan, memperbaiki, menguasai atau mempertahankan hubungan pertukaran sehingga menguntung-kan bagi pihak lain. Penjualan dapat diartikan juga sebagai usaha yang dilakukan manusia untuk menyampaikan barang bagi mereka yang memerlukan dengan imbalan uang menurut harga yang telah ditentukan atas persetujuan bersama".

Jika dilihat dari sudut manajemen pemasaran yang berorientasi pada kebutuhan dan keinginan konsumen, maka dalam hal ini perusahaan harus mengetahui apa yang menjadi kebutuhan dan keinginan konsumen, kepuasaan konsumen dapat terwujud bila konsumen mendapatkan produk yang memiliki performa sesuai harapan dan mudah diperoleh ditempat dan waktu yang tepat.

Faktor-faktor yang mempengaruhi penjualan menurut(Dharmmesta, 2006, p. 404) sebagai berikut:

a. Kondisi dan Kemampuan Penjual Kondisi dan kemampuan terdiri dari pemahaman atas beberapa masalah penting yang berkaitan dengan produk yang dijual, jumlah dan sifat dari tenaga penjual adalah:

1) Jenis dan karakteristik barang atau jasa yang ditawarkan

2) Harga produk atau jasa

3) Syarat penjualan, seperti: pembayaran, pengiriman.

b. Kondisi Pasar

Pasar mempengaruhi kegiatan dalam transaksi penjualan baik sebagai kelompok pembeli atau penjual. Kondisi pasar dipengaruhi oleh beberapa faktor yakni : jenis pasar, kelompok pembeli, daya beli, frekuensi pembelian serta keinginan dan kebutuhannya. 
c. Modal

Modal atau dana sangat diperlukan dalam rangka untuk mengangkut barang dagangan ditempatkan atau untuk membesar usahanya. Modal perusahaan dalam penjelasan ini adalah modal kerja perusahaan yang digunakan untuk mencapai target penjualan yang dianggarkan, misalnya dalam menyelenggarakan stok produk dan dalam melaksanaan kegiatan penjualan memerlukan usaha seperti alat transportasi, tempat untuk menjual, usaha promosi dan sebagainya.

d. Kondisi Organisasi

Perusahaan Pada perusahan yang besar, biasanya masalah penjualan ini ditangani oleh bagian tersendiri, yaitu bagian penjualan yang dipegang oleh orang-orang yang ahli dibidang penjualan.

e. Faktor-faktor lain

Faktor-faktor lain seperti periklanan, peragaan, kampanye, dan pemberian hadiah sering mempengaruhi penjualan karena diharapkan dengan adanya faktor-faktor tersebut pembeli akan kembali membeli lagi barang yang sama.

\section{METODOLOGI}

Agar tidak terjadi persepsi yang salah terhadap permasalahan yang akan dibahas dalam skripsi ini, maka Penulis memberikan asumsi sebagai berikut:Produk air mineral AQUA yang diteliti adalah kemasan botol berisi 600 mililiter, dengan harga bersaing dengan produk sejenis lainnya, produk yang ditawarkan oleh PT. Tirta Investama merupakan produk yang mempunyai kualitas yang baik dan sudah terdaftar di BPOM, anggaran yang digunakan untuk pelaksanaan promosi penjualan dan periklanan yang dilakukan oleh manajemen PT. Tirta Investama tidak terkendala dalam biaya, dan pendistribusian yang dilakukan oleh PT. Tirta Investama sudah berjalan dengan baik dan tersebar diberbagai macam segmen pasar di Indonesia.

Metode pengumpulan data adalah teknik atau cara yang dilakukan oleh peneliti untuk mengumpulkan data yang dilakukan untuk memperoleh informasi yang dibutuhkan dalam rangka mencapai tujuan penelitian. Pengumpulan data dilakukan dengan menggunakan metode kuesioner. Metode kuesioner tersebut berisi tentang pernyataan untuk mendapatkan informasi.

\section{HASIL DAN PEMBAHASAN}

\section{Penyajian Data}

Dalam melaksanakan strategi promosi bermacam-macam cara telah dilakukan PT. Tirta Investama sebagaiperusahaan yang tergabung dalam grupDanone, sehingga secara keseluruhan tujuan promosi yang ingin dicapai adalah untuk meningkatkan hasil penjualan dengan terus merealisasikan penjualan sesuai dengan target yang ingin dicapai, adapun program-program atau kegiatankegiatan yang telah dilakukan oleh PT. Tirta Investamadalam melakukan promosi adalah sebagai berikut: 
a. Periklanan

AQUA untuk saat ini merupakan market leader dalam medan persaingan berbagai produk air mineraldalam kemasan (AMDK)di Indonesia. Posisinya yang kuat disebabkan oleh faktor AQUA sebagai produk air mineral yang pertama kali hadir di Indonesia serta strategi promosi dan pemasaran yang gencar.Metode promosi yang digunakan adalah terutama melalui iklan di media elektronik dan cetak, mensponsori berbagai acara, serta instalasi iklan billboard secara luas.

b. Promosi Penjualan

AQUA melakukan berbagai promosi baik melalui media online, media cetak maupun saluran komunikasi lainnya.Seperti kita ketahui bahwa banyak sekali iklan produk dengan merek AQUA yang mengisi setiap iklan di televisi, radio maupun di media cetak.Inilah salah satu strategi pemasaran AQUA yang dijalankan. AQUA juga mensponsori beberapa bidang olahraga dan lainnya untuk mendongkrak popularitas merek ini agar lebih dikenal masyarakat luas.

c. Hubungan Masyarakat

Pelayanan sangat penting bagi suatu perusahaan kepada konsumennya sehingga AQUA juga memberikan pelayanan yang baik bagi konsumennya di seluruh Indonesia.Melalui distributor AQUA di seluruh Indonesia ini AQUA bisa memberikan pelayanan yang maksimal kepada pelanggannya.

Dalam pemasarannya, grup distribusi AQUA memiliki jaringan distribusi air mineral yang terluas di Indonesia, yang mana menembus sampai hampir ke setiap sudut kepulauan.Jumlah titik stok (gudang) semakin diperbanyak secara agresif sejak tahun 2005, sehingga mampu menyediakan penetrasi pasar yang lebih luas melalui rantai suplai dan penghantaran.Gudang stok ditempatkan pada area-area yang memiliki outlet retail yang banyak, termasuk pasar tradisional, sehingga setiap gudang dapat melayani masing-masing area geografis dalam waktu yang sesingkat mungkin.

Dalam melakukan analisa data ini, penulis mengumpulkan data yang mendukung penelitian melalui dokumen-dokumen yang berasal dari bagian pemasaran PT. Tirta Investamayaitu biaya promosi penjualan dan biaya periklanan yang telah dikeluarkan dan data hasil penjualan produk air mineral AQUA kemasan 600 milliliterpada periode bulan Januari 2013 sampai dengan bulan Desember 2015. Untuk mempermudah penyajian data-data yang telah berhasil dikumpulkan, data-data tersebut akan dikelompokkan dalam tabel-tabel agar lebih jelas dan kemudian akan dianalisa statistik dengan menggunakan analisa regresi linier berganda, analisa koefisien korelasi, analisa koefisien penentu, serta analisa uji hipotesis melalu uji $\mathrm{F}$ dan uji t, dengan menggunakan program pengolahan data menggunakan IBM Stastitical for Product and Service Solution (SPSS) versi 20.Sebelum analisa statistik tersebut dilakukan, terlebih dahulu akan penulis sajikan tabel biaya promosi penjualan sebagai variabel $\mathrm{X}_{1}$ dan biaya periklanan sebagai variabel $\mathrm{X}_{2}$ dan tabel hasil penjualan variabel $\mathrm{Y}$, 
pada periode bulan Januari 2013 sampai dengan bulan Desember 2015 sebagai berikut:

\section{Tabel 1}

Data Biaya Promosi Penjualan, Biaya Periklanan Dan Hasil Penjualan PT. Tirta Investama Tahun 2013 - 2015(dalam Jutaan Rp)

\begin{tabular}{clccc}
\hline Periode & \multicolumn{1}{c}{ Triwulan } & $\begin{array}{c}\text { Biaya Promosi } \\
\text { Penjualan }\left(\mathbf{X}_{\mathbf{1}}\right)\end{array}$ & $\begin{array}{c}\text { Biaya Periklanan } \\
\left(\mathbf{X}_{\mathbf{2}}\right)\end{array}$ & $\begin{array}{c}\text { Hasil Penjualan } \\
(\mathbf{Y})\end{array}$ \\
\hline \multirow{5}{*}{ Tahun 1 } & $\mathrm{Q}_{1}$ Jan - Mar 2013 & 41.730 & 59.800 & 210.000 \\
& $\mathrm{Q}_{2}$ Apr - Jun 2013 & 73.750 & 87.180 & 295.000 \\
& $\mathrm{Q}_{3}$ Jul - Sep 2013 & 61.128 & 76.410 & 260.000 \\
& $\mathrm{Q}_{4}$ Okt - Des 2013 & 62.260 & 88.500 & 283.000 \\
& $\mathrm{Q}_{1}$ Jan - Mar 2014 & 63.000 & 47.989 & 220.500 \\
Tahun 2 & $\mathrm{Q}_{2}$ Apr - Jun 2014 & 77.130 & 116.820 & 324.500 \\
& $\mathrm{Q}_{3}$ Jul - Sep 2014 & 70.560 & 88.200 & 278.200 \\
& $\mathrm{Q}_{4}$ Okt - Des 2014 & 90.775 & 107.983 & 305.640 \\
& $\mathrm{Q}_{1}$ Jan - Mar 2015 & 52.000 & 77.825 & 233.730 \\
Tahun 3 & $\mathrm{Q}_{2}$ Apr - Jun 2015 & 91.950 & 110.340 & 328.394 \\
& $\mathrm{Q}_{3}$ Jul - Sep 2015 & 75.809 & 98.784 & 303.238 \\
& $\mathrm{Q}_{4}$ Okt - Des 2015 & 97.350 & 113.468 & 336.204 \\
\hline
\end{tabular}

Analisis Data

Dalam penelitian ini tehnik analisis data yang digunakan diantaranya :

\section{a. Analisis Regresi Linier Berganda}

Analisis regresi linier berganda bertujuan untuk mengetahui pengaruh variabel bebas $(\mathrm{X})$ terhadap variabel terikat (Y). Variabel bebasnya adalah promosi penjualan $\left(\mathrm{X}_{1}\right)$ dan biaya periklanan $\left(\mathrm{X}_{2}\right)$. Sedangkan variabel terikatnya adalah hasil penjualan (Y).

Tabel 2

\section{Hasil Analisis Regresi Linier Berganda}

Coefficients $^{\mathrm{a}}$

\begin{tabular}{|c|c|c|c|c|}
\hline \multirow[t]{2}{*}{ Model } & \multicolumn{2}{|c|}{$\begin{array}{c}\text { Unstandardized } \\
\text { Coefficients }\end{array}$} & \multirow{2}{*}{$\begin{array}{c}\text { Standardized } \\
\text { Coefficients } \\
\text { Beta }\end{array}$} & \multirow[t]{2}{*}{ t Sig. } \\
\hline & $\mathrm{B}$ & Std. Error & & \\
\hline (Constant) & 99.084 & 14.124 & & 7.015 .000 \\
\hline $\begin{array}{l}\text { Biaya Promosi } \\
\text { Penjualan }\end{array}$ & .952 & .320 & & .3732 .975 .016 \\
\hline Biaya Periklanan & 1.279 & .247 & & .648 5.176.001 \\
\hline a. Dependent Varial & $\begin{array}{l}\text { enjualan } \\
\text { ber: Hasi }\end{array}$ & hitungan Data T & & \\
\hline
\end{tabular}

Berdasarkan hasil persamaan regresi tersebut, diinterpretasikan sebagai berikut:

1) Dalam persamaan regresi tersebut diketahui konstantanya adalah:99.084. Artinya tanpa dipengaruhi oleh variabel bebas maka nilai dari hasil penjualan (Y) adalah 99.084 rupiah.ini dapat diartikan bahwa tanpa adanya 
biaya promosi penjualan $\left(\mathrm{X}_{1}\right)$, dan biaya periklanan $\left(\mathrm{X}_{2}\right)$, maka hasil penjualan (Y) menunjukkan nilai sebesar 99.084 rupiah/satuan.

2) Koefisien regresi Variabel $X_{1}$ (biaya promosi penjualan) $=0.952$

Artinya setiap kenaikan $\mathrm{X}_{1}$ (biaya promosi penjualan) per $\mathrm{Rp} 1,-$, maka akan mengakibatkan kenaikan pada variable terikat $\mathrm{Y}$ (hasil penjualan) sebesar 0.952 rupiah (pola hubungan positip) dengan anggapan bahwa $\mathrm{X}_{2}$ adalah tetap.

3) Koefisien regresi Variabel $\mathrm{X}_{2}$ (biaya periklanan) $=1.279$

Artinya setiap kenaikan variable $\mathrm{X}_{2}$ (biaya periklanan) per $\mathrm{Rp} 1,-$, maka akan mengakibatkan kenaikan pada variabel $\mathrm{Y}$ (hasil penjualan) sebesar 1.279 rupiah (pola hubungan positip) dengan anggapan bahwa $\mathrm{X}_{1}$ adalah tetap).

\section{b. Analisa Koefisien Korelasi (R)}

Merupakan indeks atau bilangan yang digunakan untuk mengukur atau mengetahui kedekatan hubungan antara variabel yang disimbolkan dengan (r).

Tabel 3

Hasil Koefisien Korelasi (R)

\begin{tabular}{|c|c|c|c|c|}
\hline & & $\begin{array}{l}\text { Correlations } \\
\text { Biaya Promosi } \\
\text { Penjualan }\end{array}$ & $\begin{array}{c}\text { Biaya } \\
\text { Periklanan }\end{array}$ & $\begin{array}{c}\text { Hasil } \\
\text { Penjualan }\end{array}$ \\
\hline \multirow{3}{*}{$\begin{array}{l}\text { Biaya Promosi } \\
\text { Penjualan }\end{array}$} & $\begin{array}{l}\text { Pearson } \\
\text { Correlation }\end{array}$ & 1 & $.812^{* *}$ & $.899^{* *}$ \\
\hline & Sig. (2-tailed) & & .001 & .000 \\
\hline & $\mathrm{N}$ & 12 & 12 & 12 \\
\hline \multirow{3}{*}{ Biaya Periklanan } & $\begin{array}{l}\text { Pearson } \\
\text { Correlation }\end{array}$ & $.812^{* *}$ & 1 & $.951^{* *}$ \\
\hline & Sig. (2-tailed) & .001 & & .000 \\
\hline & $\mathrm{N}$ & 12 & 12 & 12 \\
\hline \multirow{3}{*}{ Hasil Penjualan } & $\begin{array}{l}\text { Pearson } \\
\text { Correlation }\end{array}$ & $.899^{* *}$ & $.951^{* *}$ & 1 \\
\hline & Sig. (2-tailed) & .000 & .000 & \\
\hline & $\mathrm{N}$ & 12 & 12 & 12 \\
\hline
\end{tabular}

Dari data pada tabel di atas, didapatkan nilai koefisien korelasi $\mathrm{X}_{1}$ biaya promosi penjualan adalah0,899 dengan signifikan $0.000<0,05$, dan nilai koefisen korelasi $\mathrm{X}_{2}$ biaya periklanan adalah 0,951 dengan signifikan $0,000<0,05$, dengan demikian biaya promosi penjualan dan biaya periklanan memiliki hubungan sangat kuat dan signifikan terhadap hasil penjualan air mineral AQUA kemasan 600 milliliter pada PT. Tirta Investama.

\section{c. Analisa Koefisien Korelasi Berganda}

Analisis ini untuk menguji ada atau tidaknya pengaruh yang signifikan secara simultan antara variabel biaya promosi penjualan $\left(\mathrm{X}_{1}\right)$ dan variabel biaya periklanan $\left(\mathrm{X}_{2}\right)$ terhadap variabel hasil penjualan $(\mathrm{Y})$. 



\section{Tabel 4}

\section{Hasil Pengujian Koefisien Korelasi BergandaModel Summary}

\begin{tabular}{|c|c|c|}
\hline Model & $\mathrm{R}$ & R Square Adjusted R Square Std. The error of the Estimate \\
\hline 1 & $.976^{\mathrm{a}}$ & $\begin{array}{lll}.952 & .941 & 10.307335 \\
\end{array}$ \\
\hline
\end{tabular}

Dari data pada tabel di atas, didapatkan nilai koefisien korelasi berganda $\mathrm{X}_{1}$ biaya promosi penjualan dan $\mathrm{X}_{2}$ biaya periklanan adalah sebesar 0,976. Dengan demikian biaya promosi penjualan dan biaya periklanan mempunyai hubungan yang sangat kuat dan positif terhadap hasil penjualan air mineral AQUA kemasan 600 milliliter pada PT. Tirta Investama.

\section{d. Analisa Koefisien Penentu (Determinasi)}

Analisa koefisien penentu atau Determinasi digunakan untuk mengetahui besarnya kontribusi dari variabel $\mathrm{X}_{1}$ biaya promosi penjualan dan variabel $\mathrm{X}_{2}$ biaya periklanan terhadap hasil penjualan air mineral AQUA kemasan 600 milliliterpada PT. Tirta Investamasebagai variabel Y. Hasil koefisien determinasi adalah sebagai berikut:

\section{Tabel 5}

Hasil Pengujian Koefisien Determinasi $\left(\mathbf{R}^{2}\right)$ Model Summary

\begin{tabular}{lrrrr}
\hline Model & $\mathrm{R}$ & $\mathrm{R}$ Square & Adjusted R Square & Std. The error of the Estimate \\
\hline 1 & $.976^{\mathrm{a}}$ & .952 & .941 & 10.307335 \\
\hline a. Predictors: (Constant), Biaya Periklanan, Biaya Promosi Penjualan \\
Sumber : Hasil Perhitungan Data Tahun 2018
\end{tabular}

Dari data pada tabel 12 tersebut didapatkan nilai koefisien determinasi $\left(\mathrm{R}^{2}\right)=$ 0,952 dengan demikian variabel $\mathrm{X}_{1}$ (biaya promosi penjualan) dan variabel $\mathrm{X}_{2}$ (biaya periklanan) memiliki kontribusi sebesar 95,2\% terhadap variabel Y (hasil penjualan) dan sisanya sebesar $4,8 \%$ dipengaruhi oleh faktor-faktor lain di luar biaya promosi penjualan dan biaya periklanan yang tidak penulis teliti di antaranya harga produk, kompetitor,bauran promosi selain periklanan dan promosi penjualan misalnya penjualan pribadi (personal selling), publisitas (publicity),dan hubungan masyarakat atau pelayanan.

\section{e. Pengujian Hipotesis}

\section{1) Uji Statistik t}

Uji t dilakukan untuk melihat signifikansi pengaruh variabel bebas secara sendiri-sendiri (parsial) terhadap variabel terikat dengan menggangap variabel lain bersifat konstan. Pengujian ini dilakukan dengan membandingkan nilai signifikan $\mathrm{t}_{\text {hitung }}$ masing-masing variabel bebas. 


\section{Tabel 6}

Hasil Uji Statistik t

Coefficients $^{\mathrm{a}}$

\begin{tabular}{|c|c|c|c|c|}
\hline \multirow[t]{2}{*}{ Model } & \multicolumn{2}{|c|}{$\begin{array}{l}\text { Unstandardized } \\
\text { Coefficients }\end{array}$} & \multirow{2}{*}{$\begin{array}{c}\text { Standardized } \\
\text { Coefficients } \\
\text { Beta }\end{array}$} & \multirow[t]{2}{*}{ t Sig. } \\
\hline & B & Std. Error & & \\
\hline (Constant) & 99.084 & 14.124 & & 7.015 .000 \\
\hline $\begin{array}{l}\text { Biaya Promosi } \\
\text { Penjualan }\end{array}$ & .952 & .320 & & . 3732.975 .016 \\
\hline Biaya Periklanan & 1.279 & .247 & & 6485.176 .001 \\
\hline
\end{tabular}

a. Dependent Variable: Hasil Penjualan

Sumber : Hasil Perhitungan Data Tahun 2018

a) Berdasarkan hasil penelitian yang tertera pada tabel di atas, diketahui bahwa nilai signifikan variabel $\mathrm{X}_{1}$ Biaya Promosi Penjualan adalah sebesar $0,016<5 \%(0,016<0,05)$, dengan demikian to $<$ t $\alpha$ maka Ha (hipotesis alternatif) diterima dan Ho(hipotesis nihil) ditolak. Artinya Biaya Promosi Penjualan secara parsial berpengaruh signifikan terhadap hasil penjualan produk air mineral AQUA kemasan 600 milliliter pada PT. Tirta Investama.

b) Nilai signifikan untuk variabel $\mathrm{X}_{2}$. Biaya Periklanan $0.001<5 \%$ $(0,001<0,05)$, dengan demikian $t_{0}<t_{\alpha}$, maka $H_{a}$ (hipotesis alternatif) diterima dan $\mathrm{H}_{0}$ (hipotesis nihil) ditolak. Artinya variabel $\mathrm{X}_{2}$. Biaya Periklanan secara parsial berpengaruh signifikan terhadap hasil penjualan produk air mineral AQUA kemasan 600 milliliter pada PT. Tirta Investama.

\section{2) Uji Statistik $\mathbf{F}$}

Uji F dilakukan untuk melihat signifikansi pengaruh variabel bebas secara serentak terhadap variabel terikat. Pengujian ini dilakukan dengan membandingkan nilai signifikan $F_{\text {hitung. }}$.

\section{Tabel 7}

\section{Hasil Uji Statistik F}

\begin{tabular}{lrrrrr}
\multicolumn{6}{c}{ ANOVA } \\
\hline Model & Sum of Squares & df & Mean Square & F & Sig. \\
\hline Regression & 18912.534 & 2 & 9456.267 & 89.008 & $.000^{\mathrm{b}}$ \\
1 Residual & 956.170 & 9 & 106.241 & & \\
Total & 19868.704 & 11 & & & \\
\hline a. Dependent Variable: Hasil Penjualan & & & \\
b. Predictors: (Constant), Biaya Periklanan, Biaya Promosi Penjualan \\
Sumber : Hasil Perhitungan Data Tahun 2018
\end{tabular}

Berdasarkan tabel di atas diketahui bahwa nilai signifikan variabel biaya promosi penjualan $\left(\mathrm{X}_{1}\right)$ serta nilai signifikan variabel biaya periklanan dan $\left(\mathrm{X}_{2}\right)=0,000$ pada derajat keyakinan $95 \%$ $(\alpha=5 \%)$ dengan demikian $\mathrm{H}_{0}$ ditolak dan $\mathrm{H}_{\mathrm{a}}$ diterima karenanilai 
signifika 0,000 lebih kecil dari $0,05(0,000<0,05)$, memberi arti bahwa secara bersama-sama variabel bebas berpengaruh signifikan terhadap variabel terikat. Artinya biaya promosi penjualan dan biaya periklanan secara simultan berpengaruh signifikan terhadap hasil penjualan produk air mineral AQUA kemasan 600 milliliter pada PT. Tirta Investama.

\section{E. SIMPULAN}

Berdasarkan hasil peneltian tentang analisa promosi penjualan dan periklanan dalam usaha meningkatkan omzet penjualan di PT. Tirta Investama maka dapat disimpulkan bahwa: Berdasarkan hasil analisis koefisien korelasi berganda didapatkan nilai koefisien korelasi $\mathrm{X}_{1}$ biaya promosi penjualan dan $\mathrm{X}_{2}$ biaya periklanan adalah sebesar 0,976. Dengan demikian biaya promosi penjualan dan biaya periklanan secara simultan mempunyai hubungan yang sangat kuat terhadap hasil penjualan air mineral AQUA kemasan 600 milliliter pada PT. Tirta Investama. Serta

Berdasarkan hasil analisa regresi linier berganda dapat diketahui bahwa setiap kenaikan variabel bebas $\mathrm{X}_{\mathbf{1}}$ (biaya promosi penjualan) per $\mathrm{Rp} 1,-$, maka akan mengakibatkan kenaikkan pada variabel terikat $\mathrm{Y}$ (hasil penjualan) sebesar Rp 0.952,- (pola hubungan positif) dengan anggapan bahwa $\mathrm{X}_{2}$ adalah tetap. Sedangkan setiap kenaikan variabel bebas $\mathrm{X}_{2}$ (biaya periklanan) per Rp 1 maka akan mengakibatkan kenaikkan pada variabel terikat Y (hasil penjualan) sebesar Rp 1.279,- (pola hubungan positif) dengan anggapan bahwa $X_{1}$ adalah tetap, dengan demikian dapat disimpulkan bahwa jika perusahaan melakukan rencana untuk menambah biaya periklanan, maupun promosi penjualan maka volume penjualan akan meningkat, akan tetapi $\mathrm{X}_{1}$ (biaya periklanan) mempunyai peranan yang lebih besar dalam meningkatkan volume penjualan dari pada $\mathrm{X}_{\mathbf{2}}$ (promosi penjualan).

Hasil analisis koefisien determinasi $\left(\mathrm{R}^{2}\right)=0,952$ atau $95,2 \%$. Hal ini berarti prosentase pengaruh biaya promosi penjualandan biaya periklanan terhadap hasil penjualanproduk air mineral AQUA kemasan 600 milliliter pada PT. Tirta Investama sebesar 95,2\% sisanya 4,8\% dipengaruhi oleh faktor-faktor lain yang tidak penulis teliti. SelanjutnyaHasil penelitian uji t menunjukkan bahwa variabel biaya promosi penjualan $\left(\mathrm{X}_{1}\right)$ secara parsial berpengaruh signifikan terhadap variabel $\mathrm{Y}$ (hasil penjualan), serta variabel biaya periklanan $\left(\mathrm{X}_{2}\right)$ secara parsial juga berpengaruh signifikan terhadap variabel $\mathrm{Y}$ (hasil penjualan) produk air mineral AQUA kemasan 600 milliliter pada PT. Tirta Investama. Kemudian berdasarkan uji hipotesisdengan uji $\mathrm{F}$ didapatkan nilai signifikan masing-masing variabel adalah 0,016 dan $0.001<5 \%(0,001<0,05)$, sehingga dapat disimpulkan bahwa secara simultan variabel bebas berpengaruh signifikan terhadap variabel terikat. Artinya variabel bebas yang terdiri dari biaya promosi penjualan $\left(\mathrm{X}_{\mathbf{1}}\right)$ danbiaya periklanan $\left(\mathrm{X}_{2}\right)$ secara bersama-sama berpengaruh signifikan terhadap hasil penjualan air mineral AQUA kemasan 600 milliliter pada PT. Tirta Investama. 


\section{DAFTAR PUSTAKA}

Alma, B. (2011). Manajemen Pemasaran dan Pemasaran Jasa (9 ed.). Jakarta, DKI Jakarta, Indonesia: Erlangga.

Dharmmesta, B. S. (2006). Manajemen Pemasaran (8 ed.). Yogyakarta, Jawa Tengah, Indonesia: Liberty.

Kotler, P. (2006). Manajamen Pemasaran: Analisis, Perencanaan, Implementasi dan Kontrol (Bahasa Indonesia ed., Vol. 1). Jakarta, DKI Jakarta, Indonesia: Prenhallindo.

Kotler, P., \& Amstrong, G. (2012). Dasar-Dasar Pemasaran. (A. Sindoro, \& B. Molan, Trans.) Jakarta, DKI Jakarta, Indonesia: Prenhalindo.

Kotler, P., \& Keller, K. L. (2007). Manajemen Pemasaran (1 ed., Vol. 1). Jakarta, DKI Jakarta, Indonesia: Erlangga.

Paryanti, A. B. (2018, Agustus). Implementasi E-Service untuk Pelayanan Prima dengan Metode Pieces Framework. CKI on SPOT, 11(1), 61-82.

Putri, R. S., \& Safri, I. (2015, Oktober). Pengaruh Promosi Penjualan dalam Meningkatkan Penjualan Mobil Mitsubishi pada PT. Pekan Perkasa Berlian Motor Pekanbaru. VALUTA: Jurnal Administrasi Bisnis, Manajemen dan Ekonomi, 1(2), 298-321. Retrieved from http://journal.uir.ac.id/index.php/valuta/article/view/1283/807

Sugiyono. (2010). Metode Penelitian Kuantitatif, Kualitatif dan R \& D. Bandung, Jawa Barat, Indonesia: Alfabeta.

Syaharuddin, A. (2015, Desember). Pengaruh Biaya Promosi terhadap Peningkatan Penjualan Rumah pada Perumahan Grand Aroepala di Makassar. Iqtisaduna, 1(2), 1-17. Retrieved from http://journal.uinalauddin.ac.id/index.php/Iqtisaduna/article/view/1191 